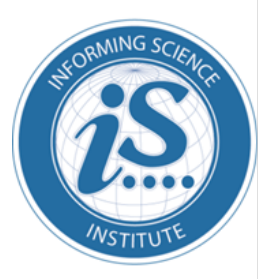

Proceedings of the Informing Science + Information Technology Education Conference

June 30 - July 4, 2019, Jerusalem, Israel

\title{
Promoting Healthy Nutrition through EDUCATIONAL ESCAPE GAMES
}

Tal Yachin*

Miri Barak

*Corresponding author
Technion - Israel Institute of Technology, Haifa, Israel

Technion - Israel Institute of

Technology, Haifa, Israel tal.yachin@,campus.technion.ac.il

bmiriam@ed.technion.ac.il

\section{ABSTRACT}

Aim/Purpose The increased production of processed food, rapid urbanization, and changing lifestyles have led to a shift in dietary patterns so people are now consuming more unhealthy foods. To change unhealthy dietary patterns, there is a need to educate the individuals to keep a balanced diet that is rich in nutritional requirements. One way to educate a heterogeneous population, from preschool to adults, is by learning through games.

Background In recent years, the use of games as a pedagogical method is gaining momentum. Game-based learning (GBL) refers to any learning environments or activities that use games to support learning and teaching. GBL enables learners to practice skills that traditional teaching may not offer and promote more efficient learning. GBL includes various types of games; one of them is escape games (EG), which have become a popular trend in the world. Because EG are a relatively new phenomenon, the research on their development and educational value is still in its initial stages.

Methodology The current study is set to develop a methodology for 'educational EG' and to examine its role in promoting knowledge, awareness, and motivation toward a healthy nutrition. The study's theoretical framework is guided by the situated learning theory, as EG are situated in a unique setting that instigates interactions between the players and between them and the learning environment. The research questions are 1. What is the educational potential of escape games? 2. Whether and how can EG promote knowledge, awareness, and motivation toward a healthy nutrition? 3 . What are the predicting factors of knowledge, awareness, and motivation toward a healthy nutrition, in the context of educational EG?

Accepting Editor: Eli Cohen | Received: December 13, 2018 | Revised: February 13, 2019 |

Accepted: February 15, 2019.

Cite as: Yachin, T., \& Barak, M.. (2019). Promoting healthy nutrition through educational escape games. Proceedings of the Informing Science and Information Technology Education Conference, Jerusalem, Israel, pp. 217-226. Santa Rosa, CA: Informing Science Institute. https://doi.org/10.28945/4362

(CC BY-NC 4.0) This article is licensed to you under a Creative Commons Attribution-NonCommercial 4.0 International License. When you copy and redistribute this paper in full or in part, you need to provide proper attribution to it to ensure that others can later locate this work (and to ensure that others do not accuse you of plagiarism). You may (and we encourage you to) adapt, remix, transform, and build upon the material for any non-commercial purposes. This license does not permit you to use this material for commercial purposes. 
Promoting Healthy Nutrition through Educational Escape Games

Contribution The research's contributions are in three levels: In the theoretical level, the study contributes a layer of knowledge on situated learning environments, offering a new model for the development and implementation of educational EG. In the methodological level, the study presents valid and reliable research tools for examining the effectiveness of educational EG. In the practical level, the study provides a tangible EG kit on healthy nutrition.

Findings Initial findings indicated on an overall increase in the participants' positive views about EG as a situated learning environment. The findings also indicated that participation in an EG has a potential to promote knowledge and awareness of nutrition-related issues. The players' motivation to learn about nutrition increased after participating in the game, mainly due to an increase in their sense of self-efficacy.

Keywords game-based learning, educational escape games, situated learning theory

\section{INTRODUCTION}

The increased production of processed food, rapid urbanization, and changing lifestyles have led to a shift in dietary patterns so people are now consuming more unhealthy foods. To change unhealthy dietary patterns, there is a need to educate individuals to keep a balanced diet that is rich in nutritional requirements (World Health Organization, 2017). One way to educate a heterogeneous population, from preschool to adults, is by learning through games (Whitton, 2012). In recent years, the use of games as a pedagogical method is gaining momentum, providing learners the opportunities to practice skills that traditional teaching may not offer (Barak, 2017; Bondar, Anastasio, Enszer, \& Burkey, 2016). Such skills are creativity, critical thinking, communication, collaboration, group decision making, and more, which are significant for 21st-century education (Kirriemuir \& McFarlane, 2004).

Educational games or game-based learning (GBL) refers to any learning environments or activities that use games to support teaching and learning (Chang, Liang, Chou, \& Lin, 2017; Vu \& Feinstein, 2017). It takes advantage of game playing to engage learners with learning assignments, in which learning and winning are both important (Whitton, 2012; Woo, 2014). In recent studies, GBL was found to enhance cognitive and social processes, acting as a motivating factor of learning (Bondar et al., 2016; Woo, 2014). GBL includes a wide range of games; educational escape games are a new trend in this field (Borrego, Fernandez, Blanes, \& Robles, 2017; Clarke et al., 2017; Hermanns et al., 2018). Educational escape games are based on the 'escape room' games. They are team-based games in which the players collaborate to solve puzzles and complete tasks. The players' aim is to escape from a physical or virtual locked room in a limited time, in order to achieve educational goals. The puzzles and tasks are varied, ranging from logical, mathematical, and analytical problems to sensory challenges. Educational escape games are a relatively new phenomenon; therefore, the exploration of how these games are used and whether they are fitted for education is yet to be examined (Nicholson, 2018).

Hence, the current study is set to develop a model for 'educational escape games' (EduEG) and to examine its role in promoting knowledge and motivation to learn about healthy nutrition. The current study's theoretical framework is guided by the situated learning theory, as escape games are situated in unique settings that instigate interactions between the players and between them and the learning environment. This paper describes the background theory and presents the educational escape games phenomenon. It outlines the research methodology, describes its findings and discusses their importance. The current study is in a developing stage, focuses on the learning outcomes among adults aged 18 to 40 . A comprehensive research will investigate the implementation of educational escape games among younger population. The study's outcomes will help to develop educational escape games on other scientific topics and to evaluate their effectiveness. 


\section{LITERATURE REVIEW}

The situated learning theory, which guides the current study, claims for dependence between the learning environment and the learning process. The following literature review describes the theory and illustrates its relation to educational escape games environments.

\section{THE SITUATED LEARNING THEORY}

The situated learning theory was first introduced as 'situated cognition' by Brown and colleagues who argued that knowledge is a product of an activity situated in the context, the environment, and the culture in which it is developed and used (Brown, Collins \& Duguid, 1989). The situated learning theory emphasizes the connection and interdependence between the learning process and the settings in which it occurs. Lave and Wenger (1991) proposed a situated learning model in which meaningful interactions between learners promote the construction of knowledge and skills. Later on, Lave (1996) argued that adding situated contexts to learning processes is insufficient. She added the idea that the ideal situated learning involves real-life actions that include social interactions and the use of tools in a given environment. Educational escape games, implements the principles of situated learning theory by simulating real-life environments and providing participants with the opportunity to perform authentic activities in a collaborative atmosphere.

Situated learning environments have several characteristics, including: a) authentic situations - reflecting the way knowledge is used in real life; b) collaborative construction of knowledge by focusing on tasks that promotes teamwork; c) reflection - giving learners the opportunity to reflect on their achievements; and d) access to expert information - exposing learners to various levels of expertise (Collins, Brown, \& Newman, 1989; Herrington \& Oliver, 2000; Lave \& Wenger, 1991). Situated learning is relevant to educational games as it provides the theoretical link between meaningful learning and game design (Klopfer, Hass \& Osterweil, 2018).

\section{EDUCATIONAL ESCAPE GAMES}

Escape game is a team-based game where players discover clues, solve puzzles and accomplish tasks in order to achieve an overall goal in a limited time. Escape game puzzles and tasks are varied, ranging from logical, mathematical, and analytical problems to sensory tasks and out-of-the-box challenges. The typical team size in an escape game ranges from three to eight players while the goal is usually escaping from a locked room within 60 minutes (Nicholson, 2015). There are different types of escape games. They can be implemented in permanent physical rooms, or in portable trailers that change their geographic location occasionally. They can be in the form of mobile kits that do not require a permanent place, cards games, tabletop games, computer games, or street games with many participants and live actors (e.g., Clarke et al. 2017; Spira, 2018). Although escape games can be implemented in different ways, most of them share common attributes like a storyline and a theme, time limitation, the need to solve challenging puzzles, and the ability to reflect on the team's actions (Nicholson, 2018). Because escape games require a diverse set of skills and knowledge to play, they can promote players' ability to cooperate and function as a team. In addition to being entertaining, they are used for education and corporate training (e.g., Wiemker, Elumir \& Clare, 2015). Educational escape games are based on the same principles of regular escape games, but the players' aim, additionally to winning the game, is to achieve educational goals.

In recent years, the trend of escape games has grown immensely. In 2014, there were 22 escape games' facilities in the US. As for mid-2017, there are more than 1950 facilities. This trend is global and still goes on (www.roomescapeartist.com). One of its results is a growing use in escape games for educational purposes. However, because they are relatively new, both regular escape games, as well as educational escape games, were almost untouched by the academic community. 
Recently, educational escape games are starting to emerge around higher education curriculums. Medical students experienced educational escape game as an alternative learning strategy for medical education (Kinio, Dufresne, Brandys, \& Jetty, 2017), and nursing students experienced escape game toolbox in pharmacology course (Hermanns et al., 2018). Educational escape games are also used to create engaging library instruction sessions in universities (e.g., Mayer \& Toates, 2016). The studies on educational escape games in higher education indicated that students found these game motivating and enjoyed the practical exercises incorporated into the game's experience (Kinio et al., 2017). Students indicated that the game was a valuable learning activity which enables consolidation of the knowledge they already had (Hermanns, 2018; Kinio et al., 2017). Students also valued the opportunity to collaborate with their peers during the game and found it to be a good platform for the promotion of teamwork.

In the context of science education, an exploratory study found that students with low grades in physics who participated in a physics escape game acquired new knowledge and improved their grades (Voros \& Sarkozi, 2017). However, educational escape games may also have disadvantages, as players may feel frustration regarding time constraints and not being able to complete the tasks. A recent study reported that as the time was nearing an end, university students became increasingly anxious to solve the riddles (Hermanns, 2018). It also identified frustration regarding verbal instructions between players, and some indicated a need for more support and directions to complete the tasks (Hermanns, 2018). Thus, there is a need for developing a model for educational escape games that take into account the game's merits and reduces its disadvantages.

Guided by the situated learning theory and the game-based learning approach, the goal of the current study is to develop an 'educational escape games' (EduEG) model and to examine its role in promoting knowledge, awareness, and motivation toward healthy nutrition. This goal raises the following research questions: 1) Whether and how can EduEGs facilitate learning outcomes related to healthy nutrition? 2) Whether and how situated learning components of EduEGs are related to learning outcomes?

\section{METHODOLOGY}

\section{THE RESEARCH ENVIRONMENT}

The intervention included participation in an educational escape game (EduEG) through the application of a mobile kit that included nine puzzles on protein consumption and healthy nutrition. The EduEG kit was developed through cooperation between experts in nutrition, science education and gamification. The game simulated a physical escape room game, its time frame was set at 45 minutes, and the optimal team size was determined to be 3 to 5 people. The game's background story described a scenario in which zombies overrun the world, attacking humans that do not eat healthy food. To survive the zombies' attack, the participant's goal is to learn about healthy food consumption and the required protein nutrients. Figure 1 describes the puzzles' scientific concepts and EduEG flow.

As shown in Figure 1, the EduEG was divided into two parts, each part represent a room. The EduEG designed in light of the situated learning environments characteristics: The puzzles demonstrated real-life situations and activities which are related to nutrition. For example, the participants were asked to calculate the energy content of a real food product, they asked to calculate proteins daily value from models of food packages, and they asked to identify complementary proteins recipes from a cookbook. The game encouraged its participants' team-work by providing them puzzles that require collaboration. The EduEG exposed the participants for professional knowledge by displaying infographics around the room and by presenting scientific knowledge in the puzzle. The EduEG was produced in English version. Each country translated it to its local languages and then conducted it among 50 participants. 


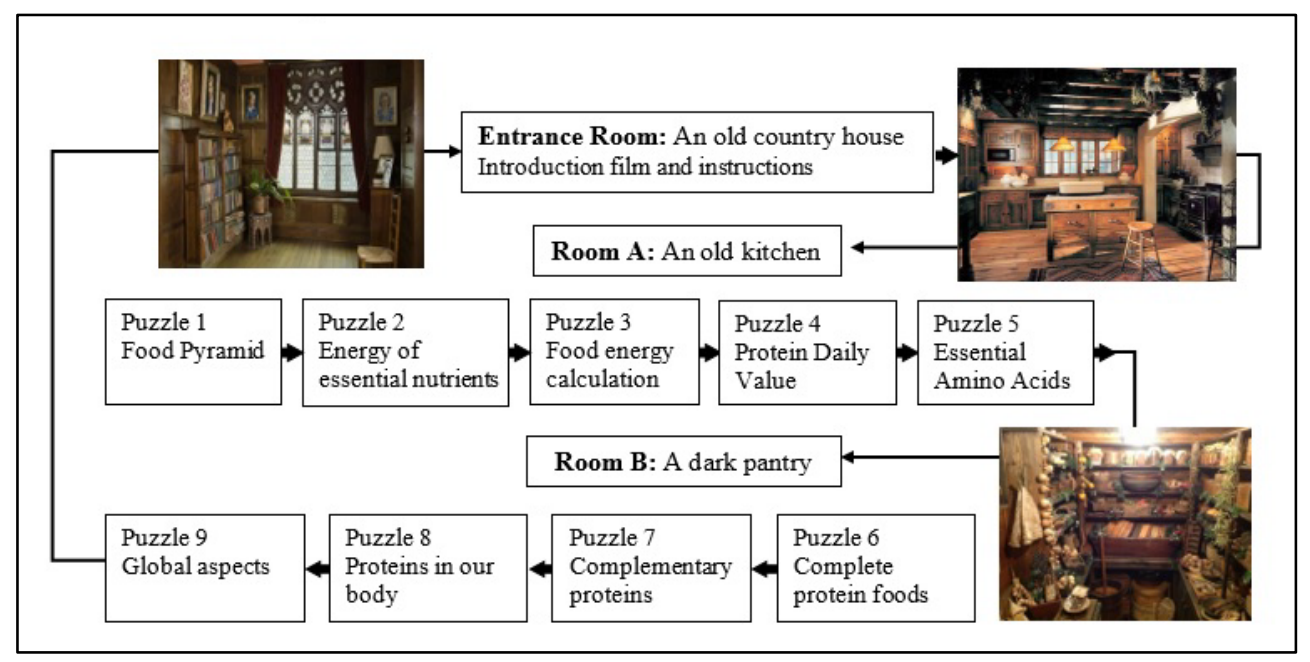

Figure 1. The EduEG concepts and flow

\section{THE RESEARCH PARTICIPANTS, PLAN AND TOOL}

The study included 239 participants aged from 18 to 40 from five countries: Belgium, Finland, Israel, Poland, and the UK. It applied pre- and post-questionnaires on knowledge and motivation to learn about healthy nutrition. The questionnaire included several parts: a) Escape game experience, which includes eight items on a 1 (strongly disagree) to 5 (strongly agree) Likert-type scale. The items are grouped into four categories, describing four situated learning components: authentic situations, teamwork, expert information, and self-reflection. These items were intended only to participants who experienced both regular escape games and the EduEG. Cronbach's alpha reliability coefficient for these items in the pre- and post- questionnaire were .88 and .82 respectively; b) Knowledge, which includes eight multiple choice questions on healthy nutrition and protein; and c) Motivation to learn about healthy nutrition, which includes 15 items on a 1 (strongly disagree) to 5 (strongly agree) Likert-type scale. The items are grouped into three categories: interest and enjoyment, connection to daily life, and self-efficacy, adapted from Barak, Ashkar, and Dori (2011). Cronbach's alpha reliability coefficient for these items in the pre- and post- questionnaire were .87 and .90 respectively. The questionnaire was administrated before and after the escape game intervention, following a repeated measures within-group design.

\section{FINDINGS}

\section{EDUEG AND LEARNING OUTCOMES}

The data normality was assessed using Shapiro-Wilk test. The results show that all the pre- and postdata violated the assumption of normality. Thus, nonparametric tests were used for the analysis.

\section{EduEG and nutritional knowledge}

The participants' knowledge about nutrition was assessed through eight multiple choice questions. Figure 2 presents the distribution of the participants by the number of their correct answers to these questions, before and after the EduEG intervention. 


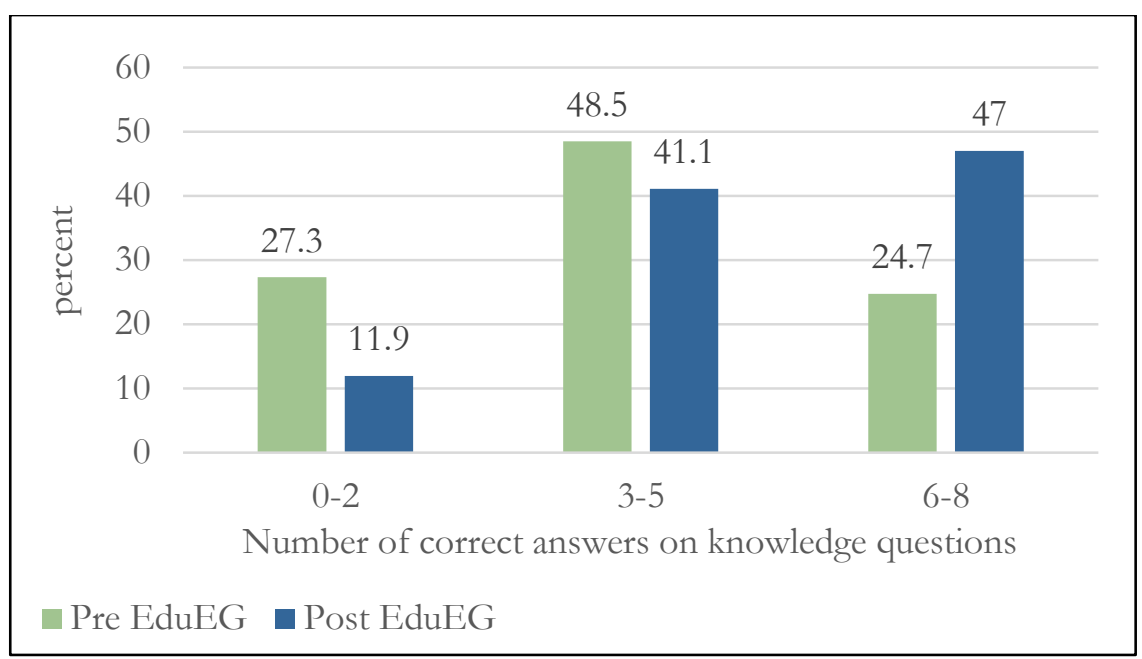

Figure 2. participants' correct answers, before and after the EduEG

As shown in Figure 2, the number of correct answers after participating in the EduEG was higher than before the participation. A Wilcoxon signed-rank test was conducted to assess this finding. The results show an increase from the pre- questionnaire $(\mathrm{M}=3.93, \mathrm{SD}=2.22)$ to the post- questionnaire $(\mathrm{M}=5.11, \mathrm{SD}=1.99)$ with statistical significance $(\mathrm{Z}=-8.09, \mathrm{p}=.000)$. A more in-depth examination shows that the significant increase was in all knowledge questions except one, as presented in Table 1.

Table 1. Percentage of participants who answered correctly on knowledge questions, and Wilcoxson signed-rank test results $(n=228)$

\begin{tabular}{lcccc}
\hline & $\begin{array}{c}\text { Pre- } \\
\text { question- } \\
\text { naire }(\%)\end{array}$ & $\begin{array}{c}\text { Post- } \\
\text { question- } \\
\text { naire }(\%)\end{array}$ & Z & p \\
\hline $\begin{array}{l}\text { Food and nutrition knowledge questions } \\
\text { 2. What many calories are there in 1 gram of protein? } \\
\quad \text { of food products? }\end{array}$ & 38.6 & 72.7 & -7.88 & .000 \\
3. How many grams of protein are recommended for & 81.1 & 90.5 & -3.67 & .000 \\
$\quad$ a person to consume per day? & 32.2 & 46.8 & -4.25 & .000 \\
4. What are essential amino acids? & 55.9 & 71.9 & -5.37 & .000 \\
5. What are complete proteins? & 62.6 & 71.9 & -2.84 & .005 \\
6. What are complementary proteins? & 33.8 & 51.3 & -5.88 & .000 \\
7. How much of the human body is protein? & 37.1 & 41.6 & -1.48 & .138 \\
8. What are the functionalities of proteins in our & 52.4 & 62.9 & -3.24 & .001 \\
body? & & &
\end{tabular}

Table 1 shows that the highest increase was of $34.1 \%$ at the question of "How many calories are there in 1 gram of protein?". Most of this increase came from participants who answered "don't know" on this question at the pre- questionnaire (47.0\%), and after the EduEG changed their answer to the correct one. The participants who answered "don't know" on this question after the game was $12.6 \%$. No significant increase was found at the question of "How much of the human body is protein?". This question was turn out to be confusing for the participants. At the post- questionnaire, an increase was found in a wrong answer. Moreover, the percentage of participants who answered "don't know" on this question at the post- questionnaire $(29.2 \%)$ was relatively high. Therefore, there is a place to assume that the message regarding this issue in the EduEG was unclear. The question with the highest percentage of participants who chose the correct answer, both at the pre- and post- 
questionnaires was "What nutrients form the basis of energy calculation of food products?". It seems that the information on this topic is already known among individuals.

\section{EduEG and motivation to learn about healthy nutrition}

A Wilcoxson signed-rank test was conducted to examine the difference in the participants' motivation to learn about healthy nutrition, before and after the EduEG. The results show an increase in the participants' motivation from the pre- questionnaire $(\mathrm{M}=3.64, \mathrm{SD}=0.72)$ to the post- questionnaire $(\mathrm{M}=3.76, \mathrm{SD}=0.69)$ with statistical significance $(\mathrm{Z}=-4.95, \mathrm{p}=.000)$.

The motivation variable was formed from three categories: interest and enjoyment, connection to daily life, and self-efficacy. Table 2 presents descriptive statistics for each category and Wilcoxson signed-rank test results, which examined the differences in the means from pre- to post- questionnaire.

Table 2. Descriptive statistics and Wilcoxson signed-rank test results for the motivation categories $(n=228)$

\begin{tabular}{lcccccc}
\hline & \multicolumn{2}{c}{ Pre- } & \multicolumn{2}{c}{ Post- } \\
questionnaire & \multicolumn{2}{c}{ questionnaire } & & \\
Motivation category & Mean! & SD & Mean! & SD & Z & p \\
\hline Interest and enjoyment & 3.95 & 0.79 & 4.04 & 0.75 & -3.23 & .001 \\
Connection to daily life & 3.64 & 0.99 & 3.73 & 0.88 & -3.17 & .002 \\
Self-efficacy & 3.33 & 0.76 & 3.51 & 0.76 & -5.86 & .000 \\
\hline
\end{tabular}

! On a scale from 1 to 5

According to table 2, the increase from pre- to post questionnaire was found to be in all categories. The total increase in motivation was derived mainly from the increase in the participants' sense of self-efficacy.

\section{LEARNING OUTCOMES AND SITUATED LEARNING COMPONENTS OF EDUEG}

From the total sample, 121 participants who experienced both regular escape games and EduEG, were asked to compare between both types of games, regarding to four situated learning components. Table 3 presents descriptive statistics of each situated learning component and a Wilcoxson signed-rank test results for the components' presence, in regular escape games and EduEG.

Table 3. Wilcoxson signed-rank test results for situated learning components, in regular escape games and in the EduEG $(n=121)$

\begin{tabular}{lcccccc}
\hline & \multicolumn{2}{c}{$\begin{array}{l}\text { Regular } \\
\text { escape games }\end{array}$} & \multicolumn{2}{c}{ EduEG } & & \\
$\begin{array}{l}\text { Situated learning compo- } \\
\text { nent }\end{array}$ & Mean! & SD & Mean! & SD & Z & P \\
\hline Authentic situation & 3.67 & 0.80 & 3.98 & 0.69 & -3.58 & .000 \\
Professional knowledge & 3.58 & 0.79 & 3.91 & 0.71 & -3.73 & .000 \\
Teamwork & 4.26 & 0.53 & 4.26 & 0.56 & -0.84 & .933 \\
Self-reflection & 3.76 & 0.73 & 3.88 & 0.78 & -1.73 & .084 \\
\hline
\end{tabular}

\footnotetext{
! On a scale from 1 to 5
} 
Promoting Healthy Nutrition through Educational Escape Games

According to Table 3, the EduEG facilitated authentic learning and access to professional knowledge. The teamwork component was perceived as dominant both in regular escape games and in the EduEG. Regarding the self-reflection component, it was more dominant in the EduEG, but with a borderline statistical significance.

The relations between the situated learning components and the learning outcomes were examined through Spearman correlation tests. The tests indicated positive statistically significant relationships between each situated learning components and participants' knowledge and motivation to learn. The highest correlation was found to be between motivation and self-reflection $\left(\mathrm{r}_{\mathrm{s}}=.43, \mathrm{p}<.001\right)$. The other correlations ranged between 0.14 to 0.27 .

\section{DISCUSSION AND CONCLUSION}

The study offered an EduEG model, which is based on situated learning environments' components. The finding shows that such a model can facilitate knowledge and motivation to learn about healthy nutrition. These findings correspond with other studies' findings, which indicated an increase in participants' knowledge and motivation following participation in educational escape games (e.g., Kinio et al., 2017; Voros \& Sarkozi, 2017). The teamwork component, which was found dominant in the EduEG environment as well as in regular escape games environments, correspond with other studies indicated that escape game environments promote collaborations (e.g., Wiemker et al., 2015). The current study found that EduEGs enhance situated learning components, which are positively correlated with educational outcomes. Thus, the current research' results strengthen the claim that gamebased situated learning environments can be used for facilitating educational goals.

The current study may have some limitations. First limitation is the research population, which included mostly university students and educated adults. Therefore, one recommendation is expanding the research to a more heterogeneous population to produce generalizable results and broader implications. Second limitation is tight research timeframe, which has not enabled to examine the finding stability during a more extended period. Thus, a longitudinal study may address this constraint. Third limitation is the lack of prior research about educational escape games. Considering the growing use in such games, this limitation enhances the need for further development of literature in this topic.

The study's contributions may be on three levels. In the theoretical level, the study contributes a layer of knowledge on game-based situated learning, offering a new model for educational escape games. This is a significant contribution to the literature as current articles on educational escape games focus on describing the storyline and puzzles (e.g., Mayer \& Toates, 2016, Voros \& Sarkozi, 2017), rather than examining their cognitive and social attributes. In the methodological level, the study presents valid and reliable research tools for examining the effectiveness of educational escape games. Practically, the study provides a detailed description of an educational escape game about healthy nutrition and a tangible kit. The kit includes the required riddles, props and locks, and a user guide for the game operators. The results of this study will help to develop educational escape games on other scientific topics and to evaluate their effectiveness.

\section{ACKNOWLEDGMENTS}

This study was sponsored by the European Institute for Innovation and Technology as part of the EIT-Food project. The project was conducted through the cooperation of five entities: the European Food Information Council (EUFIC), University of Helsinki, University of Reading, University of Warsaw, and the Technion - Israel Institute of Technology. We thank our partners whose expertise greatly assisted the research. 


\section{REFERENCES}

Barak, M. (2017). Science teacher education in the twenty-first century: A pedagogical framework for technology-integrated social constructivism. Research in Science Education, 47, 283-303. https://doi.org/10.1007/s11165-015-9501-y

Barak, M., Ashkar, T., \& Dori, J. (2011). Learning science via animated movies: Its effect on students' thinking and motivation. Computers \& Education, 56, 839-846. https://doi.org/10.1016/i.compedu.2010.10.025

Bondar, C. A., Anastasio, D., Enszer, J. A., \& Burkey, D. D. (2016). Engineers at play: Games as teaching tools for undergraduate engineering students. Journal of Engineering Education, 105, 147-200. https://doi.org/10.1002/jee.20106

Borrego, C., Fernandez, C., Blanes, I., \& Robles, S. (2017). Room escape at class: Escape games activities to facilitate the motivation and learning in computer science. Journal of Technology and Science Education, 7, 162171. https://doi.org/10.3926/jotse.247

Brown, J. S., Collins, A., \& Duguid, P. (1989). Situated cognition and the culture of learning. Educational Researcher, 81, 32-42. https://doi.org/10.3102/0013189x018001032

Chang, C. C., Liang, C., Chou, P. N., \& Lin, G. Y. (2017). Is game-based learning better in flow experience and various types of cognitive load than non-game-based learning? Perspective from multimedia and media richness. Computers in Human Behavior, 71, 218-227. https://doi.org/10.1016/j.chb.2017.01.031

Collins, A., Brown, J. S., \& Newman, S. E. (1989). Cognitive apprenticeship: Teaching the crafts of reading, writing, and mathematics. In L. B. Resnick (Ed.), Knowing, learning and instruction: Essays in honor of Robert Glaser (pp. 453-494). Hillsdale, NJ: LEA.

Clarke, S., Peel, D. J., Arnab, S., Morini, L., Keegan, H., \& Wood, O. (2017). escapeED: A framework for creating educational escape rooms and interactive games for higher/further education. International Journal of Serious Games, 4, 73-85. https://doi.org/10.17083/ijsg.v4i3.180

Hermanns, M., Deal, B., Campbell, A. M., Hillhouse, S., Opella, J. B., Faigle, C., \& Campbell, R. H. (2018). Using an "Escape Room" toolbox approach to enhance pharmacology education. Journal of Nursing Education and Practice, 8, 89-95. https://doi.org/10.5430/jnep.v8n4p89

Herrington, J., \& Oliver, R. (2000). An instructional design framework for authentic learning environments. Educational Technology Research and Development, 48, 23-48. https://doi.org/10.1007/bf02319856

Kinio, A., Dufresne, L., Brandys, T., \& Jetty, P. (2017). Break out of the classroom: The use of escape rooms as an alternative learning strategy for surgical education. Journal of Vascular Surgery, 66-76. https://doi.org/10.1016/j.jvs.2017.07.034

Kirriemuir, J., \& McFarlane, A. (2004). Report 8: Literature review in games and learning. Bristol, United Kingdom: Futurelab.

Klopfer, E., Haas, J. \& Osterweil, S. (2018). resonant games: design principles for learning games that connect hearts, minds, and the everyday. Cambridge, MA: MIT Press Ltd. https://doi.org/10.21428/6205d1a8

Lave, J. (1996). The practice of learning. In S. Chiklin \& J. Lave (Eds), Understanding practice: Perspectives on activity and context. Cambridge, UK: Cambridge University Press. https://doi.org/10.1017/cbo9780511625510.002

Lave, J., \& Wenger, E. (1991). Situated learning: Legitimate peripheral participation. New York: Cambridge University Press. https://doi.org/10.1017/cbo9780511815355.003

Mayer, B., \& Toates, U. (2016). Great escapes: Escape room games use problem-solving skills to boost curriculum. School Library Journal, 62, 14-15.

Nicholson, S. (2015). Peeking bebind the locked door: A survey of escape room facilities. Retrieved 26 August 2017 from http://scottnicholson.com/pubs/erfacwhite.pdf

Nicholson, S. (2018). Creating engaging escape games for the classroom. Childhood Education, 94, 44-49. https://doi.org/10.1080/00094056.2018.1420363 
Spira, L. (2018). Escape room in a box: The werewolf experiment - The Mattel edition. Retrieved 3 April 2018 from https://roomescapeartist.com/2018/02/01/escape-room-box-werewolf-experiment-tmattel/

Voros, A. I. V., \& Sarkozi, Z. (2017). Physics escape room as an educational tool. Retrieved 30 March 2018, from https://doi.org/10.1063/1.5017455

Vu, P., \& Feinstein, S. (2017). An exploratory multiple case study about using game-based learning in STEM classrooms. International Journal of Research in Education and Science, 3, 582-588. https://doi.org/10.21890/ijres.328087

Whitton, N. (2012). Game-based learning. In N. M. Seel (Ed.), Encyclopedia of the Science of Learning. Boston, MA: Springer.

Wiemker, M., Elumir, E., \& Clare, A. (2015). Escape room games: "Can you transform an unpleasant situation into a pleasant one?” Game Based Learning - Dialogorientierung \& spielerisches Lernen analog und digital. Brunn am Gebirge , Austria: ikon Verlag.

Woo, J. C. (2014). Digital game-based learning supports student motivation, cognitive success and performance outcomes. Educational Technology \& Society, 17, 291-307.

World Health Organization (2017). Healthy diet. Retrieved 3 December 2017, from http://www.who.int/mediacentre/factsheets/fs394/en/

\section{BIOGRAPHIES}

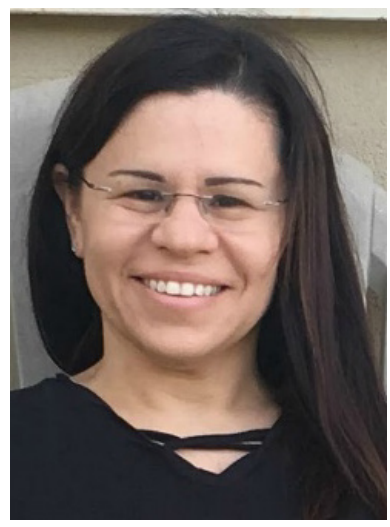

Tal Yachin is a Ph.D. candidate in the Faculty of Education in Science and Technology at the Technion, Israel Institute of Technology. Tal is a part of the faculty's science \& learning technology group. She is currently writing a dissertation on the educational role of escape games. Her research examines how educational escape games facilitate learning outcomes such as knowledge, awareness, and motivation. This research is sponsored by the European Institution for Innovation and Technology and involves collaboration between six European institutions. Tal holds a Master's degree in statistics from Haifa University (Dean's list) and a Bachelor's degree in behavioral science from Bar Ilan University (Summa Cum Laude).

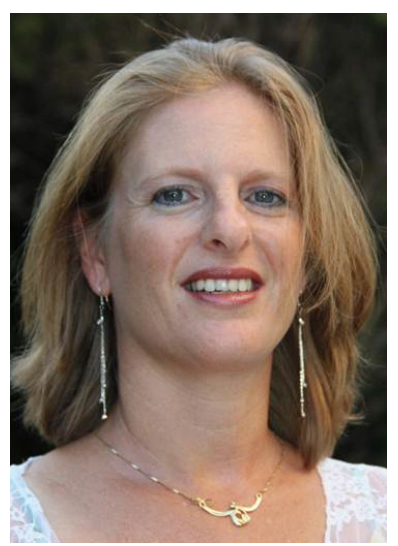

Miri Barak is a Professor in the Faculty of Education in Science and Technology, Technion, Israeli Institute of Technology. She is the Head of the Science \& Learning Technologies Group, Chair of the Technion's Behavioral Sciences Research Ethics Committee, and Assistant to the SVPR for the Promotion of Learning and Teaching. Her studies examine cognitive and sociocultural aspects of online learning in large and small groups and the promotion of innovative and flexible thinking. Her research involves the design and implementation of web-based environments such as AugmentedWorld for the advancement of 21 st century skills. She is a PI and co-PI of a number of national and international projects on location-based learning and massive online open courses (MOOCs). Her academic work is presented in more than 60 peerreviewed papers and book chapters in leading international and national publications. 